\title{
Assessment of the pollution in Aghien lagoon and its tributaries (Côte d'Ivoire, West Africa)
}

\author{
Kôkôh Rose EFFEBI ${ }^{1 *}$, Kouakou Eric ADOU $^{1}$, Thierry KOFFI ${ }^{1}$, \\ Koffi Serge EHOUMAN ${ }^{1}$ Laciné Droh GONÉ $^{1}$, Jean Louis PERRIN ${ }^{2}$, \\ Bamory KAMAGATÉ ${ }^{1}$, Noufé Djibril DABISSI ${ }^{1}$ and Luc SÉGUIS ${ }^{2}$ \\ ${ }^{I}$ University of Nangui Abrogoua, Faculty of Science and Environmental Management, \\ Geosciences and Environment Laboratory, 02 BP 801 Abidjan 02, Côte d'Ivoire. \\ ${ }^{2}$ University of Montpellier, Laboratory of Hydro Sciences Montpellier, France. \\ ${ }^{*}$ Corresponding author,E-mail: effeb2001@yahoo.fr,.Tel.: + (225) 09292549
}

\section{ACKNOWLEDGEMENTS}

This study was funded by the AMRUGE-C2D 2015-2018 program Ivorian Ministry of Scientific Research and Higher Education and the French Research Institute for Development (IRD).

\begin{abstract}
The influence of the pollutants in surface water quality when used for drinking water is of great concern in many developing countries. This study seeks to characterize the types of pollution in Aghien lagoon and its tributaries. For the sampling, water was taken at a depth of $50 \mathrm{~cm}$ from the earth surface. Samples were analyzed by the spectrometric method of molecular absorption with sulfosalicylic acid for the nitrate, spectrophotometric method of molecular absorption for the nitrites, colorimetric determination with indophenol blue for the ammonium, colorimetric method for the orthophosphates and the phosphorus, filtration method on glass fiber $(0.45 \mu \mathrm{m})$ for the Suspended Solids (SS), manometric method based on the respirometer principle for the Biochemical Oxygen Demand $\left(\mathrm{BOD}_{5}\right)$, Dichromate method for the Chemical Oxygen Demand (COD), inductively coupled plasma optical emission spectrometry (ICP-OES) technique for the heavy metals (iron, Manganese), on April and June 2015. The analysis of these physico-chemical parameters revealed that, all the year round, these waters contain real conductivity values comprised between 51 and $161.1 \mu \mathrm{S} / \mathrm{cm}$, redox potential between 100.3 and $174.4 \mathrm{mV}$; nitrate between 0.23 and $6.72 \mathrm{mg} / \mathrm{L}$. On the other hand, and over the same period, the waters of the Mé river and the channel had COD values comprised between 33 and $58.7 \mathrm{mg} / \mathrm{L}$. Concerning the Djibi rivers SS were between 36.66 and $50 \mathrm{mg} / \mathrm{L}$, dissolved oxygen between 1.46 and 1.59 $\mathrm{mg} / \mathrm{L}$; ammonium between 2.44 and $2.69 \mathrm{mg} / \mathrm{L}$ regardless the seasons. The results show that during the two seasons, the Aghien lagoon is the less polluted by the physico-chemical parameters, whereas for the same period, Mé and channel waters are the most charged with organic matters deriving from plants. As for the Djibi river, it remained the most polluted, as certified by the high values in SS and nutrient regardless of the seasons. (C) 2017 International Formulae Group. All rights reserved.
\end{abstract}

Keywords: Aghien lagoon, heavy metals, nutrients, organic matter, pollution, surface water. 


\section{INTRODUCTION}

In large cities, the access to drinking water is an important challenge to take into consideration, in order to develop the economic activities and improve the population's living conditions. Some of these cities are often supplied from subterranean waters. However, these sources are overused and often subject to pollution that impacts the quality of the waters. Anthropogenic activities of a socio-economic nature coupled with natural processes (soil erosion, precipitation, evaporation and river run-off) accelerate degradation of surface water resources (Aw et al., 2011). This view is shared by Torkil, (2004); Nanfack et al., (2014) who say that in addition to the anthropogenic activities which include pollution, poor water quality can be induced also by poor sanitation and water source hygiene. In Africa, especially in Côte d'Ivoire, lagoon environment is generally the outlet of pollution. Sewage treatment plants of urban lagoons have failed so that environment becomes vulnerable to continental waste (industrial and domestic waste) (Gouin et al., 2016). In Africa the pollution indicators are mostly noticed in the medium-sized and large cities. In the latter, the target population grows more and more, while the underground water reservoirs become progressively rare and are threatened by frequent dumping of plenty of pollutants in the environment (Kouamé, 2007).

In Côte d'Ivoire, Abidjan specially faces important problems in the supplying of drinking water. These problems are caused by an uncontrolled urbanization, and by a high rate of population growth $(5.3 \%)$. With its ten (10) cities and more than six (06) millions of people, the District of Abidjan is a real megalopolis. The intensive urbanization of the District that led to a waterproofing of the soils, the increase of its population and the recent pluviometry shortage caused an important decrease of the ground water table of Abidjan. Consequently, the District faces real problems in the access to drinking water. As a solution to this situation, it appears vital to find complementary sources of drinking water to supply the whole District. To meet this need, the Ivorian government identified the Aghien lagoon as the most important drinking water reservoir close to Abidjan.

Indeed, the Aghien lagoon is the most important fresh water reservoir near the District of Abidjan. However, it is subject to all types of pollution deriving from anthropogenic activities. That's why we must continuously keep track of the quality of its waters. The presence of organic pollutants makes difficult the treatment of raw water intended for human consumption (Adjagodo et al., 2016). Thus, several studies related to the physico-chemical and microbiologic quality of the waters from the Aghien lagoon were conducted (Traoré, et al., 2012; Traoré et al., 2014; Yéo 2015). The work by Traoré et al., (2012) and Traoré et al., (2014) was respectively related to the physico-chemical and microbiological aspects and also to the heavy metals. As for Yéo (2015), there was reference to the organic matters and to the heavy metals. For Adjagodo et al., (2016), it is important that all anthropogenic activities must be characterized with their impacts in order to limit pollution. None of these studies made reference to the space distribution of these parameters. Consequently, these works do not help determine the rate of pollution caused by the whole river basin. In order to meet this space distribution, we inserted the cartography to our work: "Assessment of the pollution in Aghien lagoon and its tributaries (Côte d'Ivoire, West Africa)". This is how we entitled our work to better understand pollution caused by the river basin.

The main objective of this work was to characterize the types of pollution in the river basin of the Aghien lagoon. By (1) quantifying the pollutants throughout the dry and the wet seasons, and (2) knowing the 
space-time distribution of the pollutants and determining their origins.

\section{MATERIALS AND METHODS \\ Study area}

The Aghien lagoon is located in the District of Abidjan, in the South of Côte d'Ivoire. This water reservoir is comprised between the $5^{\circ} 22^{\prime} \mathrm{N}$ and $5^{\circ} 26^{\prime} \mathrm{N}$ latitudes and the $3^{\circ} 49^{\prime} \mathrm{W}$ and $3^{\circ} 55^{\prime} \mathrm{W}$ longitudes. It partially occupies the whole Abidjan, Anyama and Bingerville (Bedia et al., 2009; Humbert, 2012; Traoré et al., 2012). The Aghien lagoon covers an area of $20 \mathrm{~km}^{2}$ wide and a perimeter of $40.72 \mathrm{~km}$, and has an estimated volume of $25 \mathrm{~km}^{3}$, with a maximal depth of 13 meters. The Aghien lagoon is part of the Abidjan lagoon system. It is separated from the Ebrié lagoon by the Potou lagoon, whose river basin is watered by a hydrographic system composed of the Béte River and the Djibi River. Both run into its upstream. The Mé river also runs into the Aghien lagoon on its downstream side (Traoré et al., 2012), (Figure $1)$.

The main waters that supply the Aghien lagoon are the direct rainfalls, the waters from the two upstream tributary rivers and the underground waters. The area we selected for our work has a tropical climate, characterized by four (4) seasons: a dry season that takes place from December to March, a heavy rainy season from April to July, a lesser dry season from August to September and a lesser rainy season from October to November.

In the past, the river basin was mainly recovered with the evergreen thick tropical rain forest. But now, this same area is progressively cleared for the planting of palm and rubber trees and is occupied by the growing population in the cities around Abidjan (Azaguié and Anyama).

\section{Materials used for water analysis}

For the work, we used in situ measuring material (numerical camera, GPS, pHmeter $( \pm 0.3)$, turbidimeter, multi parameter, Niskin flask, polyethyelene made flask, cooler), laboratory equipment (scale, stove, dessicator, mineralizator, spectrophotometer DR 6,000).

\section{Selection of the sampling sites}

During the dry season, the sampling took place in April and September, and in June 2015 for the wet season. Nine stations were selected (Figure 2). The measuring points on the Mé, Bété and Djibi rivers were set up in order to quantify their amount of deposits. About the Aghien lagoon these measuring points help determine the evolution of the pollutants brought in by the tributary rivers. They also help evaluate the quality of the supply.

\section{Sampling and sample analysis Water samples}

The physico-chemical parameters were analyzed on the 9 (nine) stations and within two measuring periods. The first one took place in April 2015 (relatively dry season). The last one happened in June 2015 (high rainy season). Polyethylene-made flasks were used to collect the water samples, in order to analyze the nutrients, the total nitrogen, the total phosphorus, the COD and the SS. The water samples that served for the analysis of the parameters related to the organic matters $\left(\mathrm{BOD}_{5}, \mathrm{COD}\right)$ are taken from amber glass bottles to prevent photo-degradation of the organic matter by solar rays.

\section{Sample analysis}

in situ measuring

The turbidity, the temperature, the $\mathrm{pH}$, the conductivity and the dissolved oxygen were measured in situ. The turbidity was measured with $\mathrm{HACH} 2100 \mathrm{Q}$ turbidimeter. The temperature $\left(\mathrm{T}{ }^{\circ} \mathrm{C}\right)$, the Hydrogen potential $(\mathrm{pH})$, the dissolved oxygen (DO), the 
electrical conductivity (EC) and the redox potential (RP) were all evaluated with a HQ4Od fitted with the respective accuracies of $\pm 0.3\left(0-70^{\circ} \mathrm{C}\right) ; \pm 0.002, \pm 0.01$ and \pm 0.005 .

\section{Laboratory analysis}

Samples were analyzed by the spectrometric method of molecular absorption with sulfosalicylic acid for the nitrate, spectrophotometric method of molecular absorption for the nitrites, colorimetric determination with indophenol blue for the ammonium, colorimetric method for the orthophosphates and the phosphorus, filtration method on glass fiber $(0.45 \mu \mathrm{m})$ for the Suspended Solids (SS), manometric method based on the respirometer principle for the Biochemical Oxygen Demand $\left(\mathrm{BOD}_{5}\right)$, Dichromate method for the Chemical Oxygen Demand (COD) and inductively coupled plasma optical emission spectrometry (ICPOES) technique for the heavy metals (iron, manganese). The references of these methods used for the various analyses are given in Table 1.

\section{Statistical processing of the data}

For the data in principal component analysis (PCA), we dealt with the statistical processing via the $\mathrm{R}$ Studio and XLSTAT software.

\section{Normality test and comparison of data}

These tests were carried out using the RStudio software.

\section{Normality test}

In practice, the normality test precedes the comparison test. The normality test used is that of Shapiro. Its objective is to evaluate the distribution of data. It is carried out in the following stages:

- Formulation of null hypothesis of similarity (H0) and the alternative hypothesis $(\mathrm{H} 1)$;
- Determination of the significance level of the test (alpha). The risk of error alpha represents the probability of wrongly rejecting the hypothesis $\mathrm{HO}$ and the probability $(p)$ corresponds to the variance of H0. The thresholds commonly used are $5 \%$ (significant), $1 \%$ (very significant) and $0.1 \%$ (highly significant).

\section{Comparison test}

The choice of comparison tests varies according to the nature of the data (matched or not), depending on the number of objects to be compared ( 2 or more objects) and finally according to the distribution of the data. The comparison tests are divided into parametric and non-parametric tests. In our case, the comparison concerned the physico-chemical parameters in the dry season and in the wet season (2 objects). For this purpose, parametric tests (t tests) and non-parametric tests (Wilcoxon and Mann-Whitney) were used. The objective of the comparison test is to evaluate the variation of parameters over time (dry season and wet season). The steps of the comparison tests are identical to those of the normality tests and follow the same assumptions.

\section{Principal Component Analysis (PCA) of the data}

The lines correspond to the individuals (in this case, the stations) and the columns correspond to the variables that will be the parameters analyzed. To accept that the phenomenon involved is sufficiently expressed, the cumulative sum of the contributions of the main factors selected must be about $75 \%$. As part of this work, the Spearman formula was applied using the XLSTAT software. This choice is explained by the fact that the studied system is open (surface water), so the phenomena involved are considered nonlinear. 


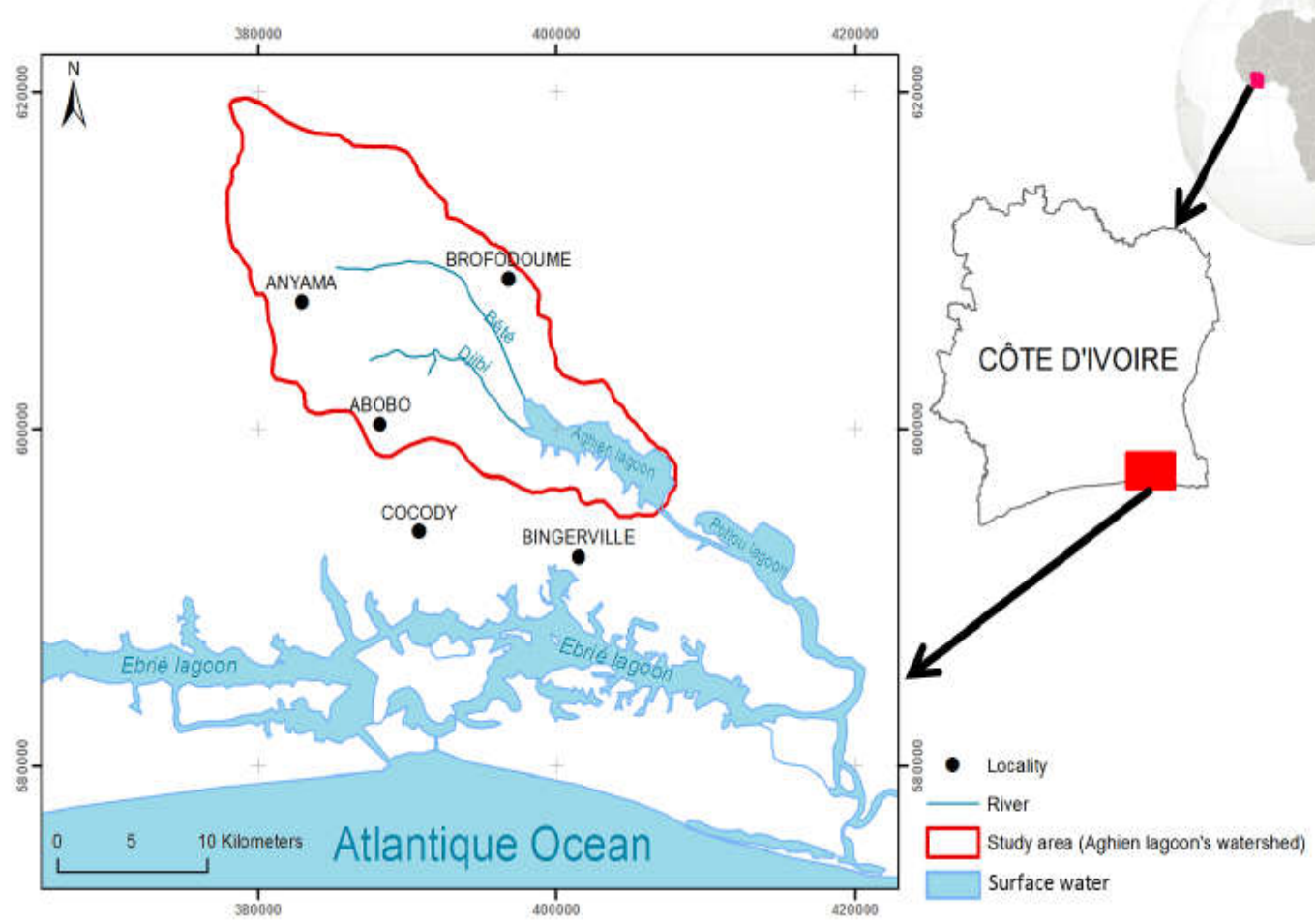

Figure 1: Watershed of Aghien lagoon (Koffi et al., 2015).

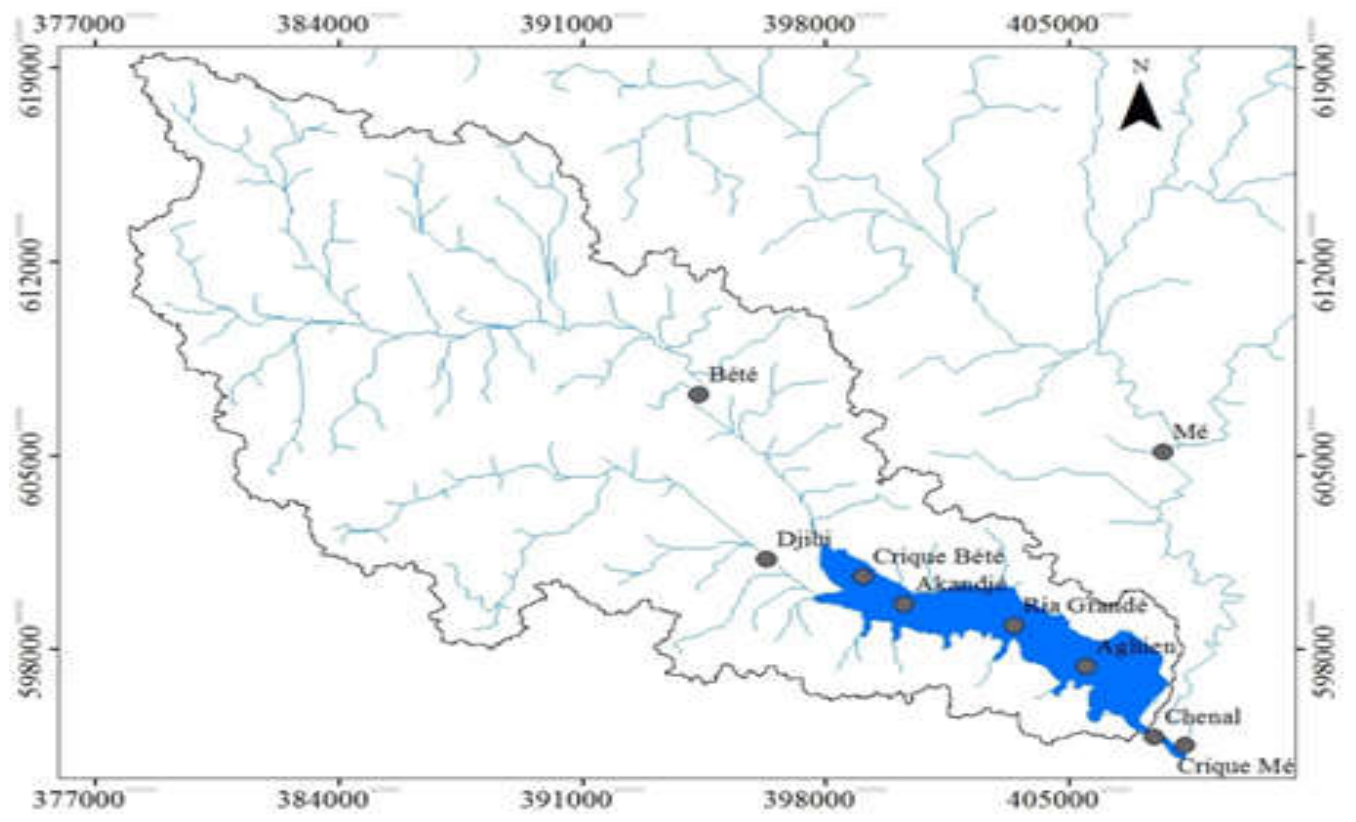

Figure 2: Geographical distribution of the sampling point. 
Table 1: Summary of the laboratory analysis methods.

\begin{tabular}{|c|c|c|}
\hline Parameters (unit) & Analysis methods & References \\
\hline Nitrate (mg/L) & Spectrometric method & French standard T 90012 \\
\hline Nitrite $(\mathrm{mg} / \mathrm{L})$ & Spectrophotometric method & French standard T 90013 \\
\hline Ammonium (mg/L) & Colorimetric method & French standard T 90015 (2000) \\
\hline Orthophosphate (mg/L) & Colorimetric method & French standard T 90023 \\
\hline Total Phosphorus (mg/L) & Colorimetric method & French standard T 90-023 \\
\hline Suspended Solids (SS) (mg/L) & Filtration method & Rodier, 2009 \\
\hline $\begin{array}{l}\text { Chemical Oxygen Demand (COD) } \\
(\mathrm{mg} / \mathrm{L})\end{array}$ & Dichromate method & AFNOR (2001) \\
\hline $\begin{array}{l}\text { Biochemical Oxygen Demand during } \\
5 \text { days }(\mathrm{BOD})(\mathrm{mg} / \mathrm{L})\end{array}$ & Manometric method & AFNOR (2001) \\
\hline Heavy metals (Fe, Mn) & Spectrophotometry method & AFNOR (2001) \\
\hline
\end{tabular}

\section{RESULTS}

\section{Physico-chemical quality of the hydrographic system}

The results of the physico-chemical analyzed are presented in Tables 2, 3, 4, and 5. These results were compared to the WHO, (2004) standards of the surface waters and to the System for Assessment of Surface Water Quality (SEQ-Eau), (MEDD et Agences de l'Eau, 2003), so as to estimate the physicochemical quality of these waters. The waters of the Aghien lagoon are alkaline (7.88 to $8.06)$ in dry periods and slightly neutral to alkaline in wet periods (6.79 to 7.69). On the other hand, the rivers (Bété, Mé and Djibi) are slightly acidic to neutral. The $\mathrm{pH}$ does not vary with seasons with probability $\mathrm{p}=0.35>$ 0.05. The waters of the Aghien lagoon are warmer $\left(25\right.$ to $\left.28.2{ }^{\circ} \mathrm{C}\right)$ than those of the rivers Bété, Mé and Djibi (25.4 and $25.8^{\circ} \mathrm{C}$ ). Temperatures do not vary with seasons with $\mathrm{p}$ $=0.37>0.05$.
As we can notice through the conductivity values (51.0 and $161.1 \mu \mathrm{S} / \mathrm{cm})$, these waters are slightly mineralized (inferior to $400 \mu \mathrm{S} / \mathrm{cm})$ in the 2 seasons, with an average of $74.47 \mu \mathrm{S} / \mathrm{cm}$. The conductivities vary little spatially over the whole catchment area except for the Djibi point. They do not vary during the seasons $(p=0.75>0.05)$. In general, the conductivities are higher in the dry season than in the wet season with the maximum values obtained in Djibi (152.1 and $161.1 \mu \mathrm{S} / \mathrm{cm}$ ). The highest redox potentials are obtained in the Mé River and in the channel. The variation of redox potential is between $100.3-174.4 \mathrm{mV}$, with an average of $137.96 \mathrm{mV}$. Turbidity $(\mathrm{p}=0.43)$ and SS $(p=0.09)$ did not vary significantly with seasons. Their wet season values are higher than in the dry season. These parameters are poorly represented in the Aghien lagoon. On the other hand, they have high values in the channel and in the Mé and Djibi rivers. The 
SS values are between $(2.5-50 \mathrm{mg} / \mathrm{L})$ with an average of $28.65 \mathrm{mg} / \mathrm{L}$.

These waters have low concentrations $0.23<$ nitrates $<6.72 \mathrm{mg} / \mathrm{L}$, with an average of $1.85 \mathrm{mg} / \mathrm{L}$, which is very far below the recommendation of the WHO, (2004), which is $50 \mathrm{mg} / \mathrm{L}$. The total nitrogen value is between $1.46-5.50 \mathrm{mg} / \mathrm{L}$ with an average of $2.63 \mathrm{mg} / \mathrm{L}$. Total nitrogen did not vary significantly $(\mathrm{p}=0.83)$ during the seasons. The Bété and Djibi rivers drain the highest concentrations of total nitrogen. In contrast to total nitrogen, nitrate variation is highly significant during the seasons with $\mathrm{p}=8.10 \mathrm{E}$ 04 . Wet season nitrate concentrations are significantly higher than in the dry season. The highest concentration is measured in the channel. Ammonium and nitrite vary significantly over time with the probabilities $p$ $=4.10 \mathrm{E}-03$ and $\mathrm{p}=0.012$ respectively. Their moist season contents are considerably higher than those of the dry season. Ammonium has high values during the rainy season at all sampling points except in the Bété and Mé rivers. As for nitrite, its maximum values are observed at the Djibi point. The ammonium is between $0.033-2.69 \mathrm{mg} / \mathrm{L}$, with an average of $1.01 \mathrm{mg} / \mathrm{L}$ in the waters of the Aghien watershed.

Dissolved oxygen $(\mathrm{p}=0.80)$ and COD $(p=0.45)$ vary in space but not significantly over time. The waters of the Aghien Lagoon are highly oxygenated with values above 6 $\mathrm{mg} / \mathrm{L}$. On the other hand, the Djibi river is very weakly oxygenated with $1.59 \mathrm{mg} / \mathrm{L}$. With regard to COD, wet season concentrations are all higher than in the dry season. Maximum COD values are obtained in the Mé River and in the Channel. The dissolved oxygen concentration noticed in the Djibi river $(1.46-1.59 \mathrm{mg} / \mathrm{L})$ show how polluted these waters are and those obtained in the Aghien lagoon are higher than $6 \mathrm{mg} / \mathrm{L}$.

We obtained also values of manganese (0.001-0.37 mg/L) with an average of 0.10 $\mathrm{mg} / \mathrm{L}$, iron $(0.119-1.6 \mathrm{mg} / \mathrm{L})$ with an average of $0.63 \mathrm{mg} / \mathrm{L}$, lower than the WHO Standards related to the surface waters, which is 50 $\mathrm{mg} / \mathrm{L}$. Iron $(\mathrm{p}=0.42)$ and manganese $(\mathrm{p}=$ 0.46 ) did not change significantly from season to season. On the other hand, their concentrations change from one measurement point to another. The maximum concentrations of $\mathrm{Fe}$ are measured in the channel and those of Mn observed in Akandjé and Mé.

Total phosphorus and ortho-phosphates did not vary significantly during the seasons, with respective probabilities $\mathrm{p}=0.75$ and $\mathrm{P}=$ 0.27 . The orthophosphate ions are in high concentrations during the two seasons. The orthophosphate varies between 0.02-0.33 $\mathrm{mg} / \mathrm{L}$ with an average of $1.11 \mathrm{mg} / \mathrm{L}$ in the waters of the Aghien watershed. These parameters are poorly represented in the Aghien lagoon as in the Mé, Bété and Djibi rivers.

\section{Space distribution of the physico-chemical parameters on the hydrographic system}

In order to obtain the space distribution of the physico-chemical parameters, the average values of these parameters were calculated from the measured values, during the dry and wet seasons. These values then enabled to obtain the cartography of the space distribution of the physico-chemical parameters (Figure 3). The space distribution indicated that the waters of the Djibi river are the less oxygenated, and have higher concentrations of nutrients (total nitrogen, ammonium, nitrate, total phosphorus and orthophosphate). As for the waters of the 
channel, the concentrations of nitrate and organic matters were the highest, whereas the waters of the Aghien lagoon had the lowest concentrations in physico-chemical parameters.

\section{Relationship between the physico-chemical parameters}

In order to establish a link between the various physico-chemical parameters, a statistical processing (Normed Principal Component Analysis (NPCA)) was applied to the overall parameters during the dry and the wet seasons. The NPCA was carried out on a data matrix composed of 09 observations (stations) and 19 variables collected during the two seasons. This enabled to underline the correlation circle graphs according to the importance of factorial axes and the individual graph. Table 6 shows the main values of the factorial axes. The first two factorial axes (F1 and F2) were selected as they both have a cumulated percentage superior to $75 \%$.

\section{Analysis of the correlation circle graph related to the F1-F2 factorial plan}

The correlation circle graph of the F1F2 factorial plan is shown in Figure 4. The analysis gives $75.55 \%$ of the whole information and shows that:

-F1 axis, with $46.55 \%$, predominates the phenomenon of acquisition of the mineralization of water by conductivity.
This mineralization is associated with variables that indicate domestic pollution such as $\mathrm{NH}_{4}{ }^{+}, \mathrm{PO}_{4}{ }^{3-}, \mathrm{TP}, \mathrm{NO}_{2}{ }^{-}$. This mineralization is opposed to the dissolved oxygen. This defines a mineralization gradient from the left side to the right side.

-F2 axis has $28.99 \%$ and is mainly associated with the COD during the dry season. However, during the wet season, this axis (F2) is associated, not only with the COD, but also with the $\mathrm{NO}_{3}{ }^{-}$and $\mathrm{PO}_{4}{ }^{3-}$ parameters. This axis indicates the acquisition of natural organic and mineral matters during the dry season.

\section{Analysis of the individual graph, related to the F1-F2 factorial plan}

The individual graph related to the F1F2 factorial plan is presented in Figure 5. The analysis of the graph provides three groups of individuals which are:

-Group I (GI) composed of points Ria Grande, Akandjé, Aghien and Crique Mé

- Group II (GII) composed of points Mé, Bété, channel and Crique Bété.

- Group III (GIII) mainly composed of the Djibi River. The waters of GI possess characteristics that are substantially similar during the two seasons. As for those of GII, their characteristics are moderately identical. Whereas, the Djibi River of GIII has characteristics that are very different from waters of GI due to their opposition on the F1 axis. 
Table 2: Physical parameters in the Aghien watershed (dry season), April 2015

\begin{tabular}{lcccc}
\hline Parameters & Channel & Aghien & Mé & Djibi \\
Hydrogen potential $(\mathrm{pH})$ & 6.5 & 7.99 & 6.75 & 6.74 \\
Temperature $\left({ }^{\circ} \mathrm{C}\right)$ & 27.21 & 28.05 & 25.4 & 25.9 \\
Conductivity $(\mu \mathrm{S} / \mathrm{cm})$ & 65.91 & 62.56 & 60.23 & 152.1 \\
Dissolved oxygen $(\mathrm{mg} / \mathrm{L})$ & 4.54 & 6.73 & 5.17 & 1.46 \\
Redox potential $(\mathrm{mV})$ & 147.52 & 121.8 & 167.4 & 129.13 \\
Turbidity $(\mathrm{NTU})$ & 37.6 & 17.13 & 35.43 & 137.3 \\
\hline
\end{tabular}

Table 3: Chemical parameters in the Aghien watershed (dry season), April 2015.

\begin{tabular}{|c|c|c|c|c|}
\hline Parameters & Channel & Aghien & Mé & Djibi \\
\hline $\mathrm{COD}(\mathrm{mg} / \mathrm{L})$ & 33 & 32 & 39 & 17 \\
\hline $\mathrm{BOD}_{5}(\mathrm{mg} / \mathrm{L})$ & 6 & 6 & $<3$ & 6 \\
\hline $\mathrm{COD} / \mathrm{BOD}_{5}$ & 5.5 & 5.33 & $>13$ & 2.83 \\
\hline $\mathrm{NH}_{4}^{+}(\mathrm{mg} / \mathrm{L})$ & 0.113 & 0.035 & 0.08 & 2.44 \\
\hline $\mathrm{NO}_{2}^{-}(\mathrm{mg} / \mathrm{L})$ & 0.013 & 0.012 & 0.013 & 0.04 \\
\hline $\mathrm{NO}_{3}^{-}(\mathrm{mg} / \mathrm{L})$ & 0.64 & 0.23 & 0.39 & 0.44 \\
\hline Total Phosphorus (mg/L) & 0.31 & 0.18 & 0.65 & 1.26 \\
\hline $\mathrm{PO}_{4}{ }^{3-}(\mathrm{mg} / \mathrm{L})$ & 0.066 & 0.02 & 0.07 & 0.33 \\
\hline Total nitrogen (mg/L) & 2.3 & 2.39 & 1.46 & 4.39 \\
\hline $\mathrm{Fe}(\mathrm{mg} / \mathrm{L})$ & 0.72 & 0.3 & 0.553 & 0.49 \\
\hline $\mathrm{Mn}^{2+}(\mathrm{mg} / \mathrm{L})$ & 0.008 & 0.007 & 0.25 & 0.07 \\
\hline Suspended Solids (mg/L) & 33.33 & 17.77 & 2.5 & 36.66 \\
\hline
\end{tabular}


Table 4: Physical parameters in the Aghien watershed (wet season), June 2015

\begin{tabular}{lcccc}
\hline Parameters & Chenal & Aghien & Mé & Djibi \\
\hline Hydrogen potential $(\mathrm{pH})$ & 5.67 & 7.69 & 6.42 & 7.1 \\
Temperature $\left({ }^{\circ} \mathrm{C}\right)$ & 24.9 & 28.0 & 25.8 & 25.8 \\
Conductivity $(\mu \mathrm{S} / \mathrm{cm})$ & 51.0 & 66.6 & 48.3 & 161.1 \\
Dissolved oxygen $(\mathrm{mg} / \mathrm{L})$ & 3.57 & 8.72 & 3.07 & 1.59 \\
Redox potential $(\mathrm{mV})$ & 174.1 & 144 & 174.4 & 100.3 \\
Turbidity $($ NTU) & 45.3 & 21.5 & 40.3 & 273 \\
\hline NTU = Nephelometric Turbidity Unit & & & &
\end{tabular}

NTU = Nephelometric Turbidity Unit

Table 5: Chemical parameters in the Aghien watershed (wet season), June 2015.

\begin{tabular}{|c|c|c|c|c|}
\hline Parameters & Chenal & Aghien & Mé & Djibi \\
\hline $\mathrm{COD}(\mathrm{mg} / \mathrm{L})$ & 58.7 & 35.0 & 52.8 & 29.2 \\
\hline $\mathrm{NH}_{4}^{+}(\mathrm{mg} / \mathrm{L})$ & 2.40 & 2.40 & 0.105 & 2.69 \\
\hline $\mathrm{NO}_{2}^{-}(\mathrm{mg} / \mathrm{L})$ & 0.056 & 0.028 & 0.059 & 0.203 \\
\hline $\mathrm{NO}_{3}^{-}(\mathrm{mg} / \mathrm{L})$ & 6.72 & 1.63 & 3.25 & 3.53 \\
\hline Total phosphorus (mg/L) & 0.330 & 0.171 & 0.166 & 1.370 \\
\hline $\mathrm{PO}_{4}{ }^{3}-(\mathrm{mg} / \mathrm{L})$ & 0.10 & 0.07 & 0.15 & 0.11 \\
\hline Total nitrogen (mg/L) & 2.40 & 2.40 & 1.95 & 5.50 \\
\hline $\mathrm{Fe}(\mathrm{mg} / \mathrm{L})$ & 1.600 & 0.378 & 0.600 & 0.119 \\
\hline $\mathrm{Mn}^{2+}(\mathrm{mg} / \mathrm{L})$ & 0.007 & 0.001 & 0.37 & 0.068 \\
\hline Suspended Solids (mg/L) & 40 & 26.66 & 40 & 50 \\
\hline
\end{tabular}

Table 6: Main values of the factorial axes.

\begin{tabular}{lcccc}
\hline & F1 & F2 & F3 & F4 \\
\hline Main value & 17.69 & 11.01 & 3.79 & 2.61 \\
Variability (\%) & 46.55 & 28.99 & 9.99 & 6.87 \\
Cumulative \% & 46.55 & 75.55 & 85.55 & 92.42 \\
\hline
\end{tabular}




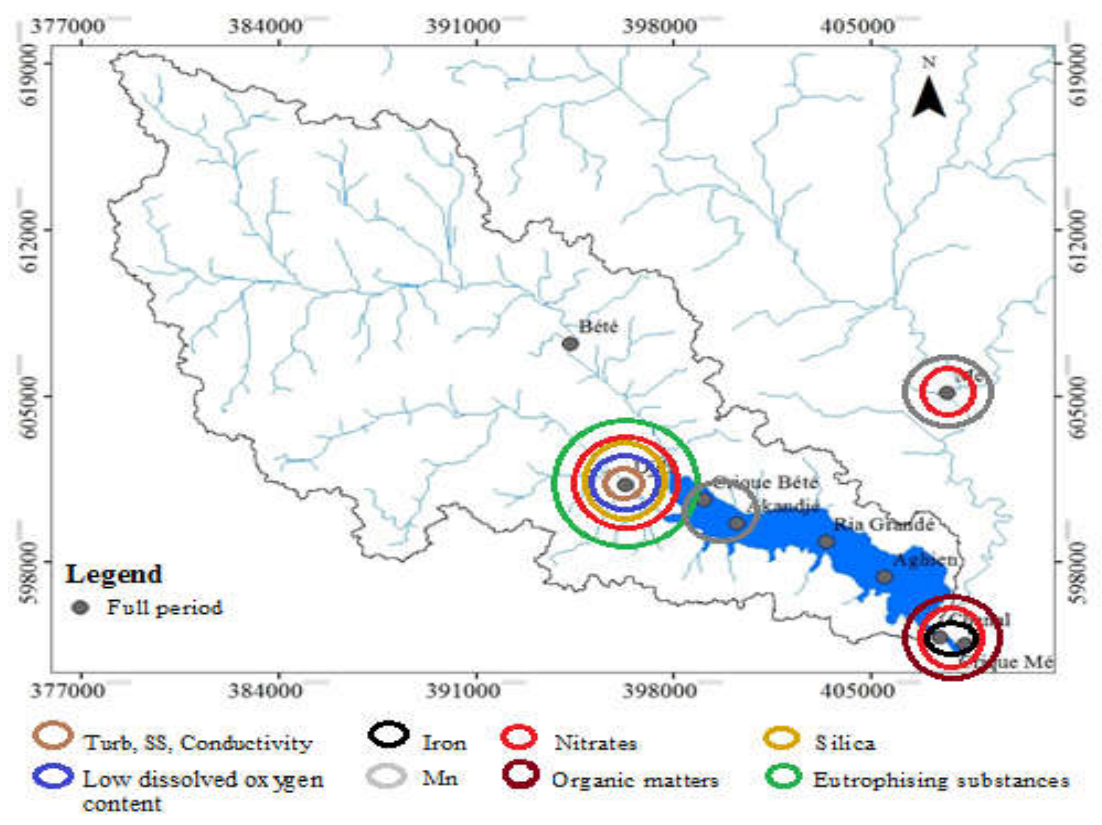

Turb: Turbidity; SS: Suspended Solids; Mn: manganese

Figure 3: Space distribution of the physico-chemical parameters within the 2 seasons.

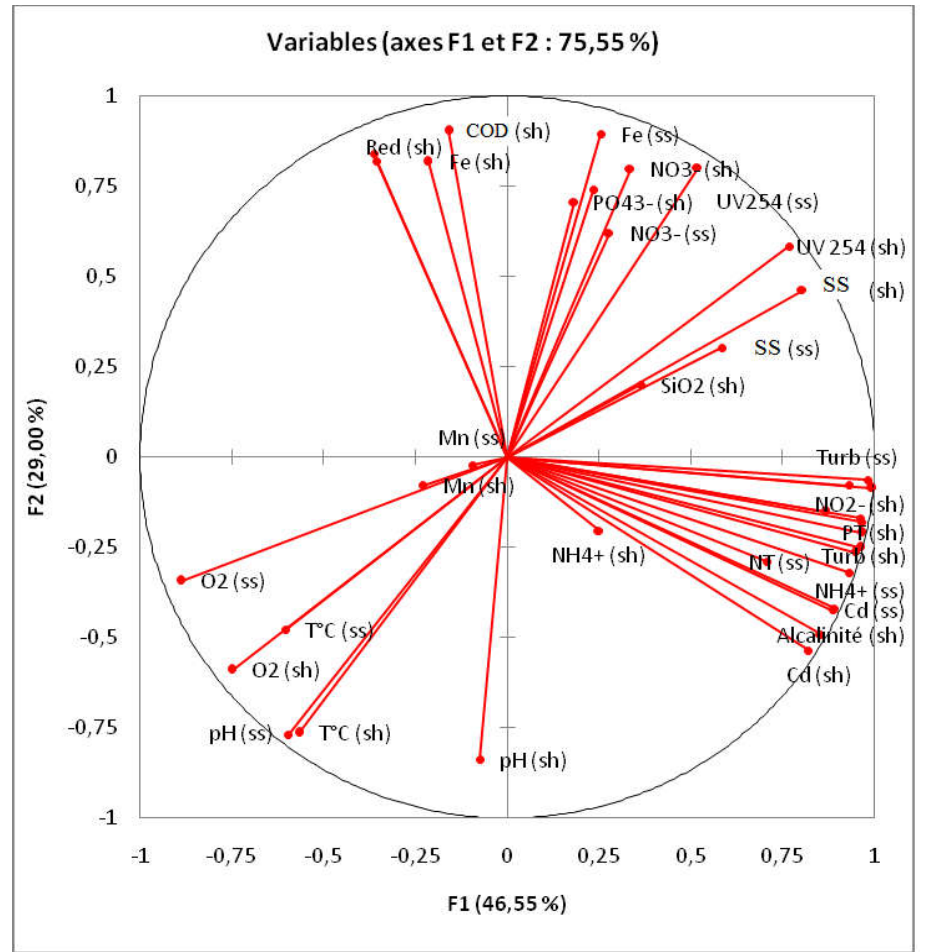

Figure 4: Correlation circle graph of the F1-F2 factorial plan. 


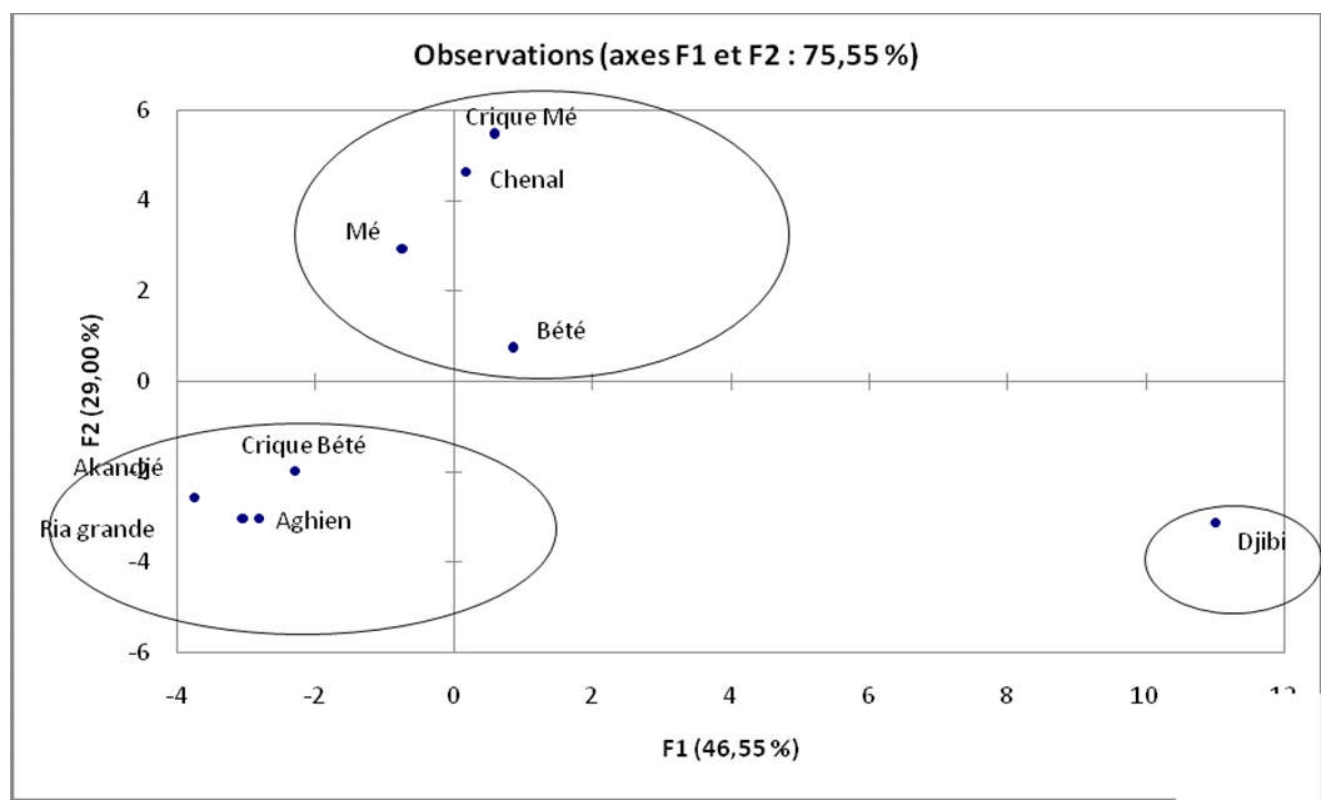

Figure 5: Individual graph related to the F1-F2 factorial plan.

\section{DISCUSSION}

The temperature values closed to the ambient temperature $\left(25-28{ }^{\circ} \mathrm{C}\right)$ are similar to those obtained by Tamungang et al. (2016), they noticed that the variation in temperature reflects the influence of the season as well as the climate of the day on water quality. The parameters $\mathrm{pH}$, conductivity, redox potential, iron and nitrates used to classify the waters of the hydrographic system in the excellent class. However, the dissolved oxygen (1.46 to 8.46 $\mathrm{mg} / \mathrm{L})$, the ammonium concentration $(0.033$ $2.69 \mathrm{gm} / \mathrm{L})$, the SS concentration $(2.5-50$ $\mathrm{mg} / \mathrm{L})$, the manganese concentration $(0.001$ $0.37 \mathrm{mg} / \mathrm{L}$ ), the total nitrogen concentration $(1.46-5.50 \mathrm{mg} / \mathrm{L})$ and the orthophosphate concentration $(0.02-0.33 \mathrm{mg} / \mathrm{L})$ indicate a real pollution of these waters. The waters in the Aghien lagoon (6.47-8.06) are alkaline, but tributary rivers are slightly acidic (5.67-7.1).

These results oppose those provided by Traoré et al. (2012), for whom the waters in the rivers are basic while those of the lagoon are acidic. This phenomenon might be explained by a flow of basic salt waters in the dry season, from the Atlantic Ocean via the Potou lagoon. Also according to the IBGE (2005), the alkalinity resulted from the geology of layers crossed by these waters. According to the IBGE (2005), the alkalinity derived to geological layers traversed by these waters. The $\mathrm{pH}$ measures the ion concentration of water. This parameter depends on a large number of physicochemical equilibria and on multiple factors including the origin of water (Aboudi et al., 2014). The Mé and Djibi rivers generally remain neutral throughout the seasons. On the other hand, the waters of the Aghien lagoon are slightly basic in the dry season.

One of the most important quality parameters for surface water remains dissolved oxygen. Indeed, dissolved oxygen concentrations make it possible to assess the quality of surface water and thus define their areas of revalorization. The dissolved oxygen levels obtained in the waters of the Aghien Lagoon and the Djibi River are particularly 
distinguished. The high concentrations of dissolved oxygen (greater than $6 \mathrm{mg} / \mathrm{L}$ ) in the waters of the Aghien lagoon indicate eutrophication of these waters caused by intense photosynthetic activity (IBGE, 2005), whereas, those of Djibi (between 1 and 2 $\mathrm{mg} / \mathrm{L}$ ) show a strong pollution of this water. This pollution is caused by the direct dumping of the sewage effluents from Abobo and Anyama, into the Djibi River. Indeed, the dissolved oxygen contents are inversely correlated with the mineralization. Thus, mineralization, induced by drainage of wastewater and domestic wastewater from the neighborhoods (Abobo and Anyama), results in the consumption of oxygen dissolved by bacteria for the degradation of organic matter in an aerobic environment. In addition, Yéo (2015) asserted that the solid matters contained in the water of the Djibi River were probably the cause of the low rates in dissolved oxygen. Seasonal variations are due to SS contributions by rain-leaching (Yéo, 2015).

The concentrations of nitrates, with an average of $1.85 \mathrm{mg} / \mathrm{L}$ in these waters are in agreement with those obtained by Ouattara et al. (2012) on the ziga dam between 0,2 et 3,4 $\mathrm{mg} / \mathrm{L}$ ). On the other hand, these values are very low compared to those obtained by Tapsoba et al. (2016) with an average value of nitrates $(5.3 \mathrm{mg} / \mathrm{l})$ during the various months of their study, also low compared to those found by Mama et al. (2011) and Somé et al. (2008), which found values of $7 \mathrm{mg} / 1$.

Like dissolved oxygen, COD is a very important parameter which makes it possible to evaluate the total organic matter content in a water. The high values, $33<\mathrm{COD}<57.7$ $\mathrm{mg} / \mathrm{L}$ in Mé, channel and crique Mé in the dry season show how these waters are full of organic matters. These high COD values are mainly due to the regular discharge of wastewater from pig farms in the vicinity of the lagoon and other domestic activities. According to Daouda et al. (2011), not only the organic matters are produced by domestic and agricultural activities, but they also derive from decays of dead animals or plants. Concerning the Aghien lagoon however, these organic matters are the results of washing, swimming, dish washing remains of food, dumping and the use of chemical fertilizers near the lagoon (Traoré et al., 2012). The pollution by nutrients $\left(\mathrm{NH}_{4}{ }^{+}, \mathrm{PO}_{4}{ }^{3-}, \mathrm{TP}, \mathrm{NO}_{2}{ }^{-}\right.$ and $\mathrm{TN}$ ) of the waters in the hydrographic system is caused by agricultural and domestic activities. During the dry season, this pollution which derives from domestic activities is mainly the fact of downthrows of wastewater from Abobo and Anyama. According to Lisec (2004) the COD/BOD report reveals that the Mé, and Bété rivers are highly biodegradable with $10<\mathrm{COD} / \mathrm{BOD}<$ 20 exactly13.5, but the Djbi river drains recently discharged wastewater with $\mathrm{COD} / \mathrm{BOD}<2.5$.

This confirms the high concentrations of nitrate, ortho-phosphate and ammonium in the Djibi River. Indeed, in aerobic environment, the low rates of dissolved oxygen in the Djibi River do not help in the complete mineralization of the nitrogen into nitrate by nitrobacter bacteria. During the wet season, this pollution mainly originates from the leaching of the cultivated soils. These assertions match with Konan et al. (2008) and those of Komoé (2010) who proved that the rain leaching is the key factor that produces nutrients in the lagoon waters.

The heavy metal concentrations $\mathrm{Fe}$ (0.119-1.6 mg/L) and Mn (0.007-0.37 mg/L) did not cause an important pollution of the river basin waters. Indeed, their concentrations are lower than the WHO standards about the surface waters $(0.5$ and 50 $\mathrm{mg} / \mathrm{L}$ for the iron and $0.4 \mathrm{mg} / \mathrm{L}$ for the manganese). The space-time evolution of the physico-chemical parameters proves that the waters of the Aghien lagoon are the least polluted among all the waters in the hydrographic system. It undergoes little influence of domestic and agricultural 
activities of the local villages, and represents the scrubbing zone waters of the watershed.

The Mé River, shows an average pollution mainly dominated by the plant organic matter. On the opposite, the Djibi River remains the most polluted of the water system, a pollution mainly caused by direct dumping of garbage and domestic waste water from Abobo and Anyama.

\section{Conclusion}

Our study was to determine the pollution of this important water reserve by the various pollutants. The analysis of water samples from the Aghien lagoon and its tributaries collected during the dry and wet seasons revealed that these waters have acceptable values of $\mathrm{pH}$, conductivity, iron, redox potential and nitrates. However, dissolved oxygen, SS, ammonium, manganese, total nitrogen and orthophosphates are strongly represented in these waters. The space-time distribution of the pollutants within the two seasons show that, the Aghien lagoon is the less polluted by the physico-chemical parameters. While during the same period, Mé and channel waters are the most charged with organic matters deriving from plants. The Djibi River remained the most polluted, as certified by the high values in SS and nutrient provided from discharge of domestic wastewater due to the absence of a sanitation system upstream of the Aghien watershed.

Overall, and considering the physicochemical parameters, we should notice that the pollution of the hydrographic system is important but remediable. However, the most alarming parameters are the nutrients. In order to use this resource to supply drinking water to the District of Abidjan, efforts need to be made both in research and in pollution control policies.

\section{COMPETING INTERESTS}

The authors declare that they have no competing interests in relation to this article.

\section{AUTHORS' CONTRIBUTIONS}

KRE supervised the entire work; EAK and TK contributed to the collection of field data, analyzed the samples and contributed to writing the manuscript. LDG and JLP collected the field data, and contributed to writing. BK and DDN contributed to the collection of data and drafting the manuscript. LS contributed to the collection of data and drafting the manuscript.

\section{REFERENCES}

Abboudi A, Tabyaoui H, El Hamichi F, Benaabidate L, Lahrach A. 2014. Etude de la qualité physico-chimique et contamination métallique des eaux de surface du bassin versant de Guigou, Maroc. European Scientific Journal, 10: 1857 - 7881.

Adjagodo A, Agassounon MDT, Kelome NC, Lawani R. 2016. Flux des polluants liés aux activités anthropiques, risques sur les ressources en eau de surface et la chaine trophique à travers le monde : synthèse bibliographique. Int. J. Biol. Chem. Sci., 10(3) : 1459-1472. DOI : http://dx.doi.org/10.4314/ijbcs.v10i3.43

AFNOR (Association Française de Normalisation). 2001. Qualité de L’Eau (Environnement) (6e edn). Association Française de Normalisation, Paris.

Aw SE, N'goran BZ, Siaka S, Parinet B. 2011. Intérêt de l'analyse multidimensionnelle pour l'évaluation de la qualité physico-chimique de l'eau d'un système lacustre tropical : cas des lacs de Yamoussoukro (Côte d'Ivoire). $J$. Appl. Biosc., 38: 2573 - 2585. ISSN 1997-5902

Bedia AT, N'zi KG, Yao SS, Kouamelan EP, N'douba V, Kouassi NJ. 2009. Typologie de la pêche en lagune Aghienpotou (Côte d'Ivoire, Afrique de l'Ouest): Acteurs et engins de pêche. Agronomie Africaine, 21, 197-204.

Daouda M, Veronique D, James B, Waris C, Benjamin Y, Baba G, Michel B. 2011. 
Caractérisation d'un Système Lagunaire en Zone Tropicale : Cas du lac Nokoué (Bénin). European Journal of Scientific Research, 56(4) : 516-528.

Humbert JF. 2012. Lagune Aghien, Rapport sur la mission, 25.

IBGE. 2005. Qualité physico-chimique et chimique des eaux de surface : cadre général. Dans : "L'eau à Bruxelles", 16p.

Gouin CA, Aka N, Adiaffi B, Bamba BS, Soro N. 2016. Pollution saisonnière des sédiments de lagune par des métaux lourds $(\mathrm{Cu}, \mathrm{Pb}$ et $\mathrm{Zn})$ en zone tropicale humide : cas de la lagune Mondoukou (Sud-Est de la Côte d'Ivoire). Int. J. Biol. Chem. Sci., 10(2): 835-845. DOI : http://dx.doi.org/10.4314/ijbcs.v10i2.31

Komoé K. 2010. Diversité du phytoplancton du complexe lagunaire de Grand-Lahou, en Côte d'Ivoire. Thèse de Doctorat de l'Université de Cocody-Abidjan, UFR Biosciences, 306p.

Konan KS, Kouassi AM, Adingra AA, Dongui BK, Gnakri D. 2008. Variations saisonnières des paramètres abiotiques des eaux d'une lagune tropicale : la lagune de Grand-Lahou, Côte d'Ivoire. European Journal of Scientific Research, 21(3) : 376-393.

Kouamé KI. 2007. Pollution physicochimique des eaux dans la zone de la décharge d'Akouédo et analyse du risque de contamination de la nappe d'Abidjan par un modèle de simulation des écoulements et $\mathrm{du}$ transport des polluants. Thèse unique. Université Abobo-Adjamé, $229 \mathrm{p}$.

Koffi KJ-P, N'Go YA, Kone D, Kouassi KH, Issiaka S. 2015. Mapping of Pollution Risk of Surface Waters by Runoff from Watershed: Case of Aghien Lagoon (South of Côte d'Ivoire). Journal of Water Resource and Protection, 7: 1457-1466.

DOI: https://doi.org/10.4236/jwarp.2015.7171 19
LISEC. 2004. Contrôle van de fysicochemische kwaliteit van de viswaters van het Brussels Hoofdstedelijk Gewest (gedurende het jaar 2003).

Mama D, Aïna M, Alassane A, Chouti W, Boukary OT, Deluchat V, Bowen J, Afouda A, Baudu M. 2011. Caractérisation physicochimique et évaluation du risque d'eutrophisation du lac Nokoué (Bénin). Int. J. Biol. Chem. Sci., 5(5) : 2076-2093. Doi: http://dx.doi.org/10.4314/ijbcs.v5i5.29

MEDD, Agences de l'eau. 2003. Système d'évaluation de la qualité de l'eau des cours d'eau (SEQ-Eau) France. Grilles d'évaluation version 2, 1-40.

Nanfack NAC, Fonteh FA, Payne VK, Katte B, Fogoh JM. 2014. Eaux non conventionnelles : un risque ou une solution aux problèmes d'eau pour les classes pauvres. Larhyss Journal, 17: 4764.

Ouattara Y, Guiguemde I, Diendere F, Diarra J, Bary A. 2012. Pollution des eaux dans le bassin du nakambe: cas du barrage de Ziga. Int. J. Biol. Chem. Sci., 6(6): 80348050. Doi : http://dx.doi.org/10.4314/ijbcs.v6i6.47

Rodier J. 2009. L'Analyse de l'Eau (9ème édn). Dunod: Paris; 1-1579.

Some K, Dembele Y, Some L, Millogo Rasolodimby J. 2008. Pollution des eaux dans le bassin du Nakambe: cas des réservoirs de Loumbila et de Mogtedo au Burkina Faso. Sud Sciences et Technologies, 16: 14-22.

Tamungang NEB, Biosengazeh NF, Alakeh MN, Tameu DY. 2016. Contrôle de la qualité des eaux domestiques dans le village Babessi au Nord-Ouest Cameroun. Int. J. Biol. Chem. Sci., 10(3): 1382-1402.

http://ajol.info/index.php/ijbcs

Tapsoba F W-B, Kere F D, Diarra J, Barry A, Sawadogo-Lingani H, Dianou D, Dicko M H. 2016. Etude de l'évolution des 
éléments précurseurs d'eutrophisation des eaux du Barrage $n^{\circ} 3$ de Ouagadougou, Burkina Faso. Int. J. Biol. Chem. Sci., 10(2): 846-859. http://www.ifgdg.org

Torkil JC. 2004. Integrated Water Resources Management (IWRM) and Water Efficiency plans by Why, What and How? Global Water Partnership.

Traoré A, Soro G, Ahoussi KE, Bamba BS, Soro N, Biemi J. 2014. Niveau de contamination en métaux lourds des sédiments d'une lagune tropicale : la lagune Aghien (Sud-Est de la Côte d'Ivoire). Afrique SCIENCE, 10(3): 73 88. http://www.afriquescience.info

Traoré A, Soro G, Kouadio EK, Bamba BS, Oga MS, Soro N, Biemi J. 2012.
Evaluation des paramètres physiques, chimiques et bactériologiques des eaux d'une lagune tropicale en période d'étiage : la lagune Aghien (Côte d'Ivoire). Int. J. Biol. Chem. Sci., 6(6): 7048-7058.

DOI: http://dx.doi.org/10.4314/ijbcs.v6i6.40

WHO. 2004. Guidelines for drinking-water quality, third edition, incorporating first addendum, 18-20. WHO.

Yéo KM. 2015. Dynamique spatiale et temporelle des caractéristiques chimiques des eaux et des sédiments, et statut trophique du système lagunaire périurbain Adjin-Potou (Côte d'Ivoire). Thèse unique. Université AboboAdjamé, 189 p. 